\title{
New Trends in Swedish Educational Research
}

\author{
Tomas Englund $\star$ \\ Örebro University, Sweden
}

\begin{abstract}
What new tendencies can be made out in Swedish educational research in the last three decades? Briefly, the following developments are described: In the 1970s, a long-prevailing emphasis on quantitative research was challenged by a number of different qualitative methods. Traditional sociology of education, meanwhile, was challenged by the new sociology of education. During the 1980s, the dominant trend was a "didacticisation" of educational research, and here two main strands can be discerned, based in phenomenography and curriculum theory. Didactics very soon made its presence felt in educational policy, and in a major evaluation of Swedish educational research the two largely didactics-based traditions of "teaching and learning" and "curriculum theory" were identified as internationally the most significant. In the 1990s, educational research took a "linguistic turn"-involving a wide-ranging shift in emphasis towards language and communication - with the result that new perspectives emerged. In addition, the philosophy of education experienced a powerful renaissance, partly as a reflection of the new focus on language and communication, but also in other respects, leading to a reawakening of interest in both classical and modern philosophy (of education).
\end{abstract}

Keywords: Educational research; Paradigms; Theoretical and methodological aspects; Turning points

\section{The Evolution of Education as a Discipline}

A tentative outline of the development of education as a discipline during the 20th century might look something like Figure 1, which shows how educational research emerged from philosophy, a link which fairly soon was weakened and almost severed altogether, only to be revived in the closing decades of the century. ${ }^{1}$ In the place of philosophy, two other "auxiliary" sciences were to set their imprint on research into education for much of the 20th century: psychology and sociology. Throughout the first half of the century, the dominant influence was psychology, and the object of study of educational science was the basic conditions at the individual level for development and learning. ${ }^{2}$ The first Swedish professor of education, Bertil

^Department of Education, Örebro University, SE 70182 Örebro, Sweden.

Email: tomas.englund@pi.oru.se

ISSN 0031-3831 (print)/ISSN 1470-1170 (online)/06/040383-14

(C) 2006 Scandinavian Journal of Educational Research

DOI: $10.1080 / 00313830600823738$ 


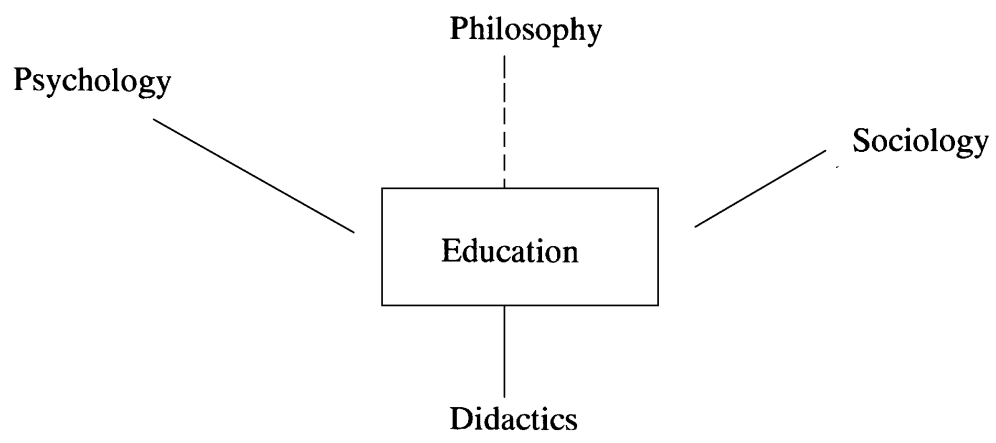

Figure 1. Education as a science

Hammer in Uppsala, admittedly had a broad spectrum of interests, including sociology, history, and philosophy, but for a long time both he and his colleagues and successors were all primarily psychological educationalists, or perhaps more accurately, educational psychologists. ${ }^{3}$

Sociology emerged as a somewhat more significant auxiliary science of education in the 1950 s and 1960s, primarily as a complement to psychology. Initially, moreover, the sociological approach addressed fundamentally the same issues as the psychological, namely the basic conditions for education, but at a social level, and the explanation for this is primarily to be found in the situation that emerged with the introduction of a 9-year compulsory comprehensive school system and a view of education as a vehicle of social mobility. ${ }^{4}$ In summary, by the end of the 1960 s educational science was established as one of the social and behavioural sciences within what can be termed social engineering, and the educational research undertaken was predominantly of a quantitative and statistical nature. There were expectations on the part of central government that research in this field would help to develop schools and society according to fairly well-defined premises. ${ }^{5}$ At the same time, though, it should be emphasised that a type of educational research was emerging that focused on the "black box", or "intermediary educational processes" (Dahllöf, 1989). This work would prove to have significant consequences for subsequent developments.

After this very brief outline of the background, we can now turn to the 1970 s, 1980s and 1990s. What were the decisive new trends and turning points in the discipline of education during these decades? ${ }^{6}$

\section{Challenges of the 1970s: A quantitative or qualitative paradigm, and a traditional or new sociology of education}

In keeping with the emphases of educational psychology-supplemented by sociological approaches, which long dominated education as a science-quantitative 
methods were all-pervading in the educational research of the 1960s. The dominant investigative paradigm was the Anglo-American mode, with great reverence for experimental design in the empirical-positivist tradition. Experimental design was regarded as the ideal, surveys as second best, and observational description as an unsatisfactory substitute (Husén, 1983, p. 88; cf. Karnung, 2001, p. 14). During the late 1960s and the 1970s, however, this dominant quantitative methodology was challenged on several fronts by those who favoured qualitative approaches. They claimed both to ask questions and to produce knowledge that was beyond the reach of traditional quantitative methods.

One qualitative approach with classical European (chiefly German) roots, which was translated and transformed into an exciting way of conducting educational research, was the hermeneutic one developed at Stockholm University by the "IMFO Group" (Immigrant and Minority Group Research), led by Arne Trankell. ${ }^{7}$ Another set of qualitative methods that was gradually imported from the AngloAmerican academic world and gained a place in Swedish educational research was what often came to be known simply as "qualitative research". This includes approaches such as ethnography, ethnomethodology, and investigative methods inspired by symbolic interactionism, anthropology, and so on. ${ }^{8}$

A third type of qualitative method, which bears a relationship to phenomenology that has been much discussed, but which was assigned a unique Swedish term and was to be the greatest influence on Swedish educational research for the foreseeable future, was what was referred to as "phenomenography". Phenomenography was developed by Ference Marton and his "INOM Group" (Learning and Conceptions of Reality Group) during the 1970s and elaborated more authoritatively in Marton (1981).

The second characteristic shift in education as a discipline in the 1970s was the change in its sociological perspective, or what came to be termed a breakthrough for the new sociology of education. That shift also had specific consequences for the emergence of the qualitative methods just mentioned.

First of all, the conceptual world of the traditional sociology of education, in which consensus and a functionalist view of society prevailed, was challenged by the conflict perspective of the new sociology of education. This shift is most clearly exemplified by Abrahamsson's essay of 1974, "Utbildning och samhälle" ("Education and society"). ${ }^{9}$

Secondly, it should be noted that the shift in favour of a critical sociology was also to have implications for the first-mentioned shift, in that exponents of the new sociology of education took a stand not only against the earlier consensus-based sociology, but also against the influence of psychology on educational research, a psychology that was considered to be coloured by the same consensus ideology as sociology. They viewed the qualitative methods emerging at this time in a similar light, perceiving them as limited, in that they lacked a societal dimension. ${ }^{10}$

Interpretations of Durkheim, Bourdieu, Bernstein, Althusser, and the capital-logic school offered a range of sociological perspectives, which were seen by a growing number of educational researchers also at this time as extremely powerful, and which 
gradually became highly influential. This was partly the result of a tidal wave of publications, of which a title such as fämlikhetsmyt och klassherravälde ("The equality myth and class dominance", Lundberg, Selander, \& Öhlund, 1976) can be regarded as typical. In these analyses, the perspective of social reproduction was paramount, and the main purpose of education was seen as the exercise of social control.

An interesting, instructive, and, for its time, successful line of development that may be noted in the perspective outlined here was the way in which a certain type of qualitative classroom research, such as Neil Keddie's interactionist-based ethnographical analysis "Classroom knowledge" (1971), ${ }^{11}$ was related to the perspective of social control. In Sweden, Staf Callewaert and Bengt A. Nilsson, in their pioneering work Samhället, skolan och skolans inre arbete ("Society, schools and the day-to-day work of schools", 1980), pursued this line further. They combined, or perhaps rather integrated, the qualitative approach into the conceptual world of the new sociology of education, and thus came to represent the new on two fronts simultaneously (cf. Englund, 1986, chap. 2.1). Swedish curriculum theory, with Ulf P. Lundgren as its leading figure and with close ties to one of the fathers of the new sociology of education, Basil Bernstein, was also built on the foundations of that movement and found eloquent expression in Lundgren (1979) (cf. Englund, 1986, chap. 3).

A point to be noted is that both of the shifts mentioned, that is, the emergence of a qualitative methodology and of the new sociology of education, coincided with major investments in research groups in many parts of the country. Were these, then, the principal changes in Swedish educational research during the 1970s? I believe that they were, although naturally it is also possible to see, in other fields, continuity and development over the same period.

\section{The 1980s: Didactics revolutionises Swedish educational research}

The most decisive shifts in education as a science during the 1980s, as I see it, relate to the emergence of didactics and the way it challenged educational research's neglect of the content issue. The shape which didactics assumed was also directly related to two of the new approaches of the 1970s highlighted earlier, phenomenography and curriculum theory, and their applications to this field. ${ }^{12}$ What was eventually to be referred to in Sweden as didaktik took shape in the early 1980s under the label of "content-related educational research", a term that served as the title of two anthologies from research conferences within the two traditions mentioned. ${ }^{13}$

Of these two traditions, phenomenographically based didactics initially had the most significant impact, and it was its foremost exponent, Ference Marton, who reintroduced the term "didactics", more specifically "content-related didactics" or fackdidaktik (Marton, 1983). Within curriculum theory in the early 1980s, a somewhat ambivalent attitude to "Swedish" didactics prevailed. If we subdivide the development of curriculum theory into three stages, ${ }^{14}$ it can be said that the second, 
social reproduction-oriented stage, which was strongly influenced by the new sociology of education, was in many respects theoretically unsympathetic to didactics, emphasising as it did the hidden curriculum of schools, their socially reproductive and controlling role, and so on. At the same time, it did lend some support to the emergence of centres for the study of didactics. ${ }^{15}$

Within the third stage of curriculum theory, didactics was much more clearly in focus, with researchers highlighting "curriculum as a political problem" (Englund, 1986). In this context, didactic analyses were gradually developed in various subject areas, scrutinising the content of the knowledge taught, and guided by the idea that "education is fundamentally not an epistemological but an ethical and political enterprise" (Schilling, 1986, p. 12; cf. Englund, 1990, p. 30, 1997, p. 279).

The didactics of the 1980s thus rested on two pillars, phenomenography and curriculum theory, whose fundamental assumptions were in many respects mutually contradictory (cf. Marton, 1986), but which at the same time, in other respects, had a great deal in common, focusing as they both did on content, though from different points of view. All in all, didactics also had an important consequence in terms of educational policy, in the sense that a government bill on teacher education endorsed the message of didactics research and argued that all prospective teachers should be trained in didactics:

that is, on questions concerning the selection of content for their teaching and concerning ways of making it comprehensible to the pupil and putting it into a context which the pupil understands and has experience of. An analysis of teaching materials forms part of teacher education in this respect. ("Lärarutbildning", 1985, p. 11)

To a large extent, early didactics spoke a traditional language of education and envisaged a school made up of teachers and students in their traditional roles, though with specific qualities. The significance which I here consider the two didacticsoriented traditions mentioned to have had, in terms of transforming Swedish educational science during the 1980 s, also finds clear confirmation in an international evaluation sponsored by the Swedish Council for Research in the Humanities and Social Sciences (HSFR) (Rosengren \& Öhngren, 1997). Describing the revolution which educational research underwent during this period, the HSFR study noted that, by the mid-1990s, two traditions could be seen as dominant and internationally successful: "teaching and learning" and "the curriculum theory tradition".

Obviously, the changes and shifts that took place in the 1980s have retained much of their significance to the present day. However, it can be said that they came to be situated in a rapidly changing societal context as the developments of the 1990s unfolded, developments which are perhaps not yet entirely apparent to us. Like history in general, the history of how educational research has changed may reasonably be expected to become more difficult to write, the closer we get to our own day. And of course, in the light of the changes of the 1990s, it is also possible to test the assumptions entailed by those of the 1970s and 1980s, and indeed of even earlier periods. 


\section{The 1990s: A linguistic and communicative turn, and a renaissance for the philosophy of education}

Can changes corresponding to those discerned for the 1970s and 1980s also be described for the 1990s? Yes, but it has to be said first that they are perhaps not as distinct and as clearly shaped by particular traditions as before and, secondly, that they are perhaps more a matter of abstract shifts in perspective. At the same time, a struggle over concepts and the "politics of naming", as a manifestation of a linguistic and a communicative turn, has assumed an increasingly dominant place. I would argue that these new focuses on language and communication, which can per se be understood in many different ways and which to a large extent are mutually integrated, are a characteristic feature of this period.

More precisely, the meaning of the "turns" referred to can be expressed in terms of a growing awareness both of the way in which language constitutes our perception of reality, and of the meaning-creating function of communication. Closely linked to these changes in outlook is a simultaneous elevation of philosophical perspectives, which is hardly surprising, given that they are to a large extent bound up with philosophy. During the 1990s, philosophy of education gradually took over, if not every university department of education, then at least the educational discussion. At the same time, we are talking here about shifts of a relatively abstract and sophisticated nature, with no obvious and significant short-term impact on the wider public debate.

One important factor behind this trend in educational research in the 1990s can, I believe, be described in the light of a comparison with the basic conditions prevailing during the previous two decades. Whereas the shifts of the 1970s helped to develop education as a socially critical science, in direct contrast to the situation in the two decades that had gone before, when educational science emerged as one of the important technologies of social engineering, the move towards didactics in the 1980s meant that educational research was readmitted to the drawing room of educational policymaking to a certain extent at least, even though the concept of didactics was not accepted in the centre-right media. But in the 1990s-when school education was perceived in public debate as representing an outmoded, "one size fits all" approach, a traditional view of schooling was reinstated, and independent schools were set up - new basic conditions were gradually created for education as a science, above all because of the factors mentioned, but also as a result of the multicultural situation and new research initiatives concerning the "founding values" of education.

Already in the closing years of the 1980s, the problems of schooling were redefined by, among others, a group of educational researchers who, in a preparatory study for government bills dealing with questions of responsibility for and management of schools (du Rietz, Lundgren, \& Wennås, 1987), portrayed the existing school system as uniform and monolithic. But the criticism which really counted-in the sense that it enjoyed authoritative status by virtue of its strong position in the media and its appeal to tradition — and which was thus able to transform the educational landscape 
found expression above all in the opinion pages of the national daily Dagens Nyheter. This media criticism of schools, like the preparatory study mentioned above, found clear support and a manifest theoretical starting point in the government-initiated Study of Power and Democracy in Sweden (SOU 1990: 44), which called into question the Swedish model of democracy. The authors of that study were probably largely unaware of and uninterested in current trends in educational research and didactics, but with their criticism of existing democratic arrangements they also steered the educational debate towards new starting points. ${ }^{16}$ This debate became part of a new educational policy rhetoric, a rhetoric that was concerned with the new needs of a growing middle class in the field of education, in terms of parental participation, private schools as an alternative to publicly funded ones, and so on.

The trend described can be seen as part of an international, conservative(Reagan- and Thatcher-) inspired process of restructuring which left educational policy and educational research in quite a different position from before, and which in Sweden was consolidated by the centre-right government that held office from 1991 to 1994 . The process had begun much earlier, and was not immediately halted by the Social Democrats' return to power in 1994 (cf. Boréus, 1994; Schüllerqvist, 1996; Telhaug, 1990). This also created new conditions for a view of schooling as involving an unproblematic concept of knowledge, linked to an evaluation system, and for the rapid growth of independent schools, with the result that schooling was now, to a greater extent, regarded as a civil right.

The educational debate had thus changed significantly and, paradoxically, the rapidly developing, dynamic, and in many respects successful research in education and didactics conducted in Sweden, and highlighted in the HSFR evaluation, had relatively little impact on Swedish public debate in this area in the 1990s. It was often completely ignored, a phenomenon that can largely be attributed to the Swedish media. This was the case even before the shift in educational research of which we have spoken, but the same shift can also be regarded partly as a response to the displacement of educational science from centre stage, that is, a refusal to go along with the demands which the return to traditional views of schooling implied. ${ }^{17}$

Briefly, as a result of the system change in educational policy between 1985 and 1995 (cf. Englund, 1996), education as a science was sidelined in the broader media debate in so far as it refused to accept the new premises of traditional schooling and independent forms of education. At the same time it can be said that Swedish educational research was extremely creative and continued to develop during the 1990s, underpinned by the fact that the interest in learning had probably never been greater. New, exciting perspectives also evolved, perspectives that have perhaps yet to gain a place in the mass media, being confined to a somewhat more restricted, intradisciplinary discussion within educational research.

Once again, what were the important shifts in Swedish educational research during the 1990s? At the beginning of this section I referred to them as a linguistic and communicative turn and a renaissance for the philosophy of education. In certain respects, these changes can be regarded as a direct continuation of the 
traditions of the 1980s, and in part they can be said to have reinforced already established positions, although in many cases they also guided them in new directions. What is of interest in that regard, as I see it, is that the linguistic and communicative turn had both a cynical and an idealistic side to it, expressed most effectively by Rorty in his comparison of Dewey and Foucault:

One can emphasise, as Dewey did, the moral importance of the social sciences-their role in widening and deepening our sense of community and of the possibilities open to this community. Or one can emphasise, as Michel Foucault does, the way in which the social sciences have served as instruments of the "disciplinary society", the connection between knowledge and power rather than that between knowledge and human solidarity. (Rorty, 1982, p. 203)

The vocabulary employed by Foucault thus incorporates, as a rule, a disciplinary aspect, and thereby follows in the classic footsteps of the new sociology of education, viewing education as a form of social control and symbolic violence. Dewey's vocabulary, on the other hand, recognises the potential of language to promote solidarity and change, especially when it is put to work in communicative contexts, when meaning is created and re-created through argumentative communication-as can happen in education. ${ }^{18}$

It is also from this latter point of view that, as didactics has continued to evolve, learning research and curriculum theory research have converged to some extent and turned to classic writers such as Bakhtin, Vygotsky, Mead, and Dewey, who all, in their various ways, emphasised the significance of communication. ${ }^{19}$ The "sociocultural" approach to learning, established in Sweden in the 1990s and more fully elaborated in Säljö (2000), is one example of a pivotal further development in this regard, and entails in certain respects a critique of the phenomenographical perspective, and one which clearly opens a door to communication. ${ }^{20}$ The "third stage" of curriculum theory-along with several strands within the renaissance of philosophy of education, most clearly that of pragmatism-exhibits the same opening up to intersubjectivity and the prior conditions for communication. ${ }^{21}$

In many respects, the linguistic and communicative turn entailed a revitalisation of educational-philosophical perspectives, and indeed was largely based on philosophical perspectives, with Richard Rorty (1980, 1982), mentioned above, and Richard Bernstein (and especially his Beyond Objectivism and Relativism, 1983) as central figures. But the interest shown in these philosophers can also be regarded as a manifestation of a broader "philosophical turn" in education as a science, a reorientation which has brought philosophical points of departure much more sharply into focus than before. Here mention should also be made of other communication-oriented philosophers, such as Habermas and Gadamer, but we may in addition note a growing interest in several figures from the history of philosophy, from Aristotle to Levinas and Derrida.

Should postmodernism not be seen as one of the new trends, then? For sure, postmodern elements can also be discerned, although no very significant study has 
yet been made of such elements in Swedish educational research. There may also be some uncertainty as to what is to be regarded as postmodern and what is part and parcel of the linguistic and communicative turn. Features which the two have in common can perhaps be said to be their rejection of foundational values and objective "Truths" with a capital $\mathrm{T},{ }^{22}$ their embracing of the principle of fallibilism (which of course also coincides with the late-modern theory of science), and their emphasis on contingency and pluralism. But when the postmodern perspective goes a step further, making a sharp distinction between private and public and rejecting all forms of universalism, then it is clearly saying things with which modernity and modern pragmatism would not agree. ${ }^{23}$

The rapid growth in interest in the philosophy of education in recent years is extremely multifaceted (see, for example, "Philosophy of education", 2001), and it is also closely bound up with the revival of political philosophy that began with Rawls (1971). The relationship between the two is one which, in recent decades, has gained visibility in the field of tension between communitarianism and liberalism and which has been brought into focus by a view of education as a civil right, challenging the earlier dominant idea of education as a social right (cf. Englund, 1993, 1994). ${ }^{24}$

What developments, then, have I missed? Obviously a good many, since I have made a selection that has specifically sought to highlight conditions that have paved the way for new approaches, and there is probably no point in even beginning to list some of the trends that I have failed to mention. I have, for example, passed over in complete silence the fact that new areas of educational research came into existence in the course of the 1990s. Many other traditions and approaches, besides those mentioned here, have coloured and shaped both the continuity of educational research and the changes it has undergone. My aim has been to draw attention to a number of important shifts that have been and remain of significance to this day, and I invite others to offer alternative reflections on the subject.

\section{A Questioning of Education as a Discipline and a Plethora of Alternative Terms: The politics of naming as a problem for educational research}

What I would call "the politics of naming", and the basic conditions for educational research today, also find concentrated expression (if we choose to consider the matter from that point of view) in the plethora of new designations for the different forms of educational research that now exist (cf. Englund, 1998). In the case of didactics, I consider it reasonable and desirable that subject didactics should evolve outside as well as inside educational science, and here collaboration with other disciplines is often natural and necessary. At the same time, I would very much like to see it existing in a close relationship and open communication with educational science (although self-criticism among subject didacticians can never be taken for granted). I regard such communication as a criterion of quality and as a crucial responsibility which the disciplines concerned, specialised subject didactics and educational research, all share. 
As for other so-called new designations, such as "learning", "pedagogical work" (pedagogiskt arbete), and so on, advocated largely by (former) educational researchers, I am dubious about their value and see them very much as a matter of staking out territory. In addition, inevitable but unnecessary confusion arises, for example between "pedagogical work" and "didactics". Possibly, with the creation of a research council-like body for the educational sciences, ${ }^{25}$ funding considerations may carry a good deal of weight. However, it would seem a risky business from a quality point of view to launch new disciplines if the aim of those concerned is to distinguish themselves from and reject education as a science, which provides the core of the critical mass required for a scholarly public discourse on educational issues.

\section{Notes}

1. This article is based on a paper given at a conference on education as a discipline, held in Jönköping, Sweden, in October 2003. My article makes no claim to be exhaustive, or to do complete justice to the discipline's development. My aim, rather, is to draw attention to a number of distinct turning points and trends which I believe have been of significance for the way we view educational research today. In doing so, I have chosen to focus on theoretical and methodological aspects of the object of study of this discipline.

2. The strength of this concern with the basic conditions for education at the individual level is made clear by the title given to a symposium marking the 80th birthday of Emeritus Professor Kjell Härnqvist, and to the resultant special issue of the journal Pedagogisk Forskning $i$ Sverige ("Individuella förutsättningar", 2002). It is also interesting to note that as recently as the early 1990s, when on the initiative of the Swedish Council for Research in the Humanities and Social Sciences (HSFR) an evaluation was to be made of the discipline of education, it was suggested by researchers in Gothenburg that it should deal with "education and educational psychology". Educational researchers on the east coast of Sweden protested, however, and in the end it was decided that the study should be concerned simply with "research in education".

3. See Forskning om Utbildning ("Pedagogik som vetenskap", 1992) for a more detailed analysis of Hammer's significance.

4. A now well-known concept from the early sociology of education in Sweden is that of a "reserve of ability" (begåvningsreserv), a concept which researchers in this field "discovered" and linguistically constructed, and which also played a part in gradually changing the "reality" of education.

5. The emphasis in the research of the late 1960s on social development, closely linked to the 1969 national curriculum for compulsory education, can be seen as an explicit manifestation of such expectations.

6. It should be noted that I shall exclude a number of important trends, which can primarily be seen as further developments of already established research approaches. The emphasis will instead be on what I regard as new trends and turning points that have changed the emphases of educational research.

7. For a brief, very slanted and critical, but nevertheless informative review of the IMFO Group's research, see Kallós and Lundgren (1974).

8. For surveys of qualitative research traditions, chiefly in the United States and United Kingdom, see Jacob (1987), and Atkinson, Delamont, and Hammersley (1988); cf. Karnung (2001). 
9. Abrahamsson's paper (1974) was originally written for a government inquiry on the internal work of schools.

10. Daniel Kallós and Ulf P. Lundgren were important pioneers in both these respects, through an article in the British fournal of Educational Psychology (Kallós \& Lundgren, 1975) and their paper mentioned in Note 7 (Kallós \& Lundgren, 1974).

11. Keddie's analysis was published in Michael Young's Knowledge and Control (1971), which launched the new sociology of education, and was translated into Swedish in Fämlikhetsmyt och klassherravälde (Lundberg et al., 1976). From the point of view outlined subsequently in this article, it is to be noted that the communicative approach was present in British classroom research during the 1970s (cf. Barnes, 1976), and even now, Keddie's critical analysis merits our attention.

12. Of course, both phenomenography and curriculum theory influenced other fields of educational research in many different ways, but here I have chosen to focus on the most far-reaching change in which both these emphases were involved, namely the establishment of didactics.

13. The two reports referred to are that edited in 1981 by Åke Gillström, Kjell Härnqvist, and Karl-Gustav Stukát, Innehållsrelaterad pedagogisk forskning ("Content-related educational research"), and a volume of conference proceedings with exactly the same title, produced the same year within the framework of the Curriculum Theory Project (edited by the project's leading researchers, Ulf P. Lundgren, Gunilla Svingby and Erik Wallin).

14. The three stages in question are the ones identified in my own article in Forskning om Utbildning (Englund, 1990, cf. Englund, 1997).

15. Specifically, I am thinking of the establishment of the Didactics Centre at the then Stockholm Institute of Education, which over a period of many years successfully introduced German and other research in didactics.

16. See, for example, Berg (1992), Englund (1994), Lindblad and Wallin (1993).

17. This picture can of course be discussed, but what is clear is that educational research faced stiff competition from other disciplines, which were far more ready to endorse traditional perceptions of school education, and the research into schools undertaken by economists and political scientists thus appeared to be more important than that conducted by educational researchers, at least in the eyes of the centre-right media.

18. See Fournal of Curriculum Studies ("The public and the text", 1996) for further discussion.

19. A point to be noted here is that educational psychology, which was mentioned earlier, is now staging a comeback, albeit in a new guise.

20. See, for example, Säljö (1990, 1992, 1994, 1995), and the interesting discussion in Nordisk Pedagogik between Marton and Säljö in 2000-2001 (Marton, 2000; Säljö, 2001).

21. Examples of this broad spectrum of approaches include issues of Utbildning och Demokrati ("Didaktik", 1998; "Undervisning", 1993), the development of "deliberative conversations" (Englund, 2000), and a large number of doctoral theses, several of which are followed up in Englund (2004); from a Nordic point of view, a recent example is Dysthe (2003). Also to be noted in this context is a greater openness towards the aesthetics of communication in a broad sense.

22. See Carl-Anders Säfström (1994), who considers this and other problems in relation to education as a discipline and problematises the epistemology of educational research, and Säfström and Östman's anthology Textanalys ("Text analysis", 1999), which provides a sampler of text analysis strategies in this spirit of a rejection of objective truths.

23. This is to touch briefly on a set of issues whose discussion would require a great deal more space.

24. Here, too, numerous studies could be cited, including some forming part of the project Democracy, Autonomy and Community (see Englund, 2004 for further documentation), but I do not regard this as my principal concern here. The key point to be noted, as I see it, is that the "educational and political philosophy" file was also opened during the 1990s.

25. The Committee for Educational Science within the Swedish Research Council was established in 2001 . 


\section{References}

Abrahamsson, B. (1974). Utbildning och samhälle. Några problemområden [Education and society. A number of problems; in Swedish]. In Skolan som arbetsplats [Schools as places of work]. [DsU 1974:1] 293-342. Stockholm: Utbildningsdepartementet.

Atkinson, P., Delamont, S., \& Hammersley, M. (1988). Qualitative research traditions: A British response to Jacob. Review of Educational Research, 58(2), 231-250.

Barnes, D. (1976). From communication to curriculum. Harmondsworth, England: Penguin.

Berg, G. (1992). Changes in the steering of Swedish schools: A step towards "societification of the state”. Fournal of Curriculum Studies, 24(4), 327-344.

Bernstein, R. (1983). Beyond objectivism and relativism. Oxford, England: Blackwell.

Boréus, K. (1994). Högervåg: Nyliberalism och kampen om språket $i$ svensk offentlig debatt 1969-1989 [A right-wing surge: Neoliberalism and the struggle for language in Swedish public debate, 1969-1989; in Swedish]. Stockholm: Tiden.

Callewaert, S., \& Nilsson, B. A. (1980). Samhället, skolan och skolans inre arbete [Society, schools and the day-to-day work of schools; in Swedish]. Lund, Sweden: Lunds universitet, Sociologiska institutionen.

Dahllöf, U. (1989). Har det svenska pedagogikämnet någon identitet? [Does Swedish educational research have an identity? in Swedish]. Forskning om Utbildning, 16(4), 4-13.

Didaktik [Didactics]. (1998). Utbildning och Demokrati, 7(2).

Dysthe, O. (Ed.). (2003). Dialog, samspel och lärande [Dialogue, interaction and learning; in Swedish]. Lund, Sweden: Studentlitteratur.

Englund, T. (1986). Curriculum as a political problem: Changing educational conceptions with special reference to citizenship education. Lund, Sweden: Studentlitteratur.

Englund, T. (1990). På väg mot en pedagogiskt dynamisk analys av innehållet [Towards an educationally dynamic analysis of content; in Swedish]. Forskning om Utbildning, 17(1), 19-35.

Englund, T. (1993). Utbildning som "public good" eller "private good": Svensk skola i omvandling [Education as a "public good" or a "private good": Swedish schools in flux; in Swedish]. [Pedagogisk forskning i Uppsala 93]. Uppsala, Sweden: Uppsala universitet, Pedagogiska institutionen.

Englund, T. (1994). Education as a citizenship right - a concept in transition: Sweden related to other western democracies and political philosophy. Fournal of Curriculum Studies, 26(4), 383-399.

Englund, T. (Ed.). (1996). Utbildningspolitiskt systemskifte? [A system change in educational policy? in Swedish]. Stockholm: HLS Förlag.

Englund, T. (1997). Towards a dynamic analysis of the content of schooling: narrow and broad didactics in Sweden: Fournal of Curriculum Studies, 29(3), 267-287.

Englund, T. (1998). Jag tror på ämnet pedagogik även i framtiden [I believe in a future for education as a discipline; in Swedish]. Pedagogisk Forskning $i$ Sverige, 3(1), 74-76.

Englund, T. (2000). Deliberativa samtal som värdegrund: Historiska perspektiv och aktuella förutsättningar [Deliberative conversations as a value foundation: Historical perspectives and current preconditions; in Swedish]. Stockholm: Skolverket.

Englund, T. (Ed.). (2004). Skillnad och konsekvens. Mötet lärare-studerande och undervisning som meningserbjudande [Difference and consequence. The teacher-student encounter and teaching as an offering of meaning; in Swedish]. Lund, Sweden: Studentlitteratur.

Gillström, Å., Härnqvist, K., \& Stukát, K.-G. (Eds.). (1981). Innehållsrelaterad pedagogisk forskning [Content-related educational research; in Swedish]. Stockholm: Skolöverstyrelsen.

Husén, T. (1983). Educational research and the making of policy in education: An international perspective. Minerva, 21(1), 81-100.

Individuella förutsättningar för utbildning [Individual prerequisites for education]. (2002). [Special issue]. Pedagogisk Forskning $i$ Sverige, 7(3). 
Jacob, E. (1987). Qualitative research traditions: A review. Review of Educational Research, 57(1), $1-50$.

Kallós, D., \& Lundgren, U. P. (1974). Att förstå eller inte förstå: Är det frågan? [To understand or not to understand: Is that the question? in Swedish]. Forskning om Utbildning, 1(2), $17-27$.

Kallós, D., \& Lundgren, U. P. (1975). Educational psychology: Its scope and limits. British fournal of Educational Psychology, 45(2), 111-121.

Karnung, G. (2001). Röster om kvalitativ forskning. En karaktäristik utifrån vetenskapliga texter [Voices on qualitative research. A characterization based on academic texts; in Swedish]. [Uppsala Studies in Education 97]. Uppsala, Sweden: Acta Universitatis Upsaliensis.

Keddie, N. (1971). Classroom knowledge. In M. Young (Ed.), Knowledge and control. New directions for the sociology of education (pp. 133-160). London: Macmillan.

Lärarutbildning för grundskolan [Teacher education for the compulsory comprehensive schools]. (1985) [Prop. 1984/85:122]. Stockholm: Riksdagen.

Lindblad, S., \& Wallin, E. (1993). On transitions of power, democracy and education in Sweden. fournal of Curriculum Studies, 25(1), 77-88.

Lundberg, S., Selander, S., \& Öhlund, U. (Eds.). (1976). Fämlikhetsmyt och klassherravälde [The equality myth and class dominance; in Swedish]. Lund, Sweden: Cavefors.

Lundgren, U. P. (1979). Att organisera omvärlden. Introduktion till läroplansteori [Organizing the world about us. An introduction to curriculum theory; in Swedish]. Stockholm: Liber.

Lundgren, U. P., Svingby, G., \& Wallin, E. (Eds.). (1981). Innehållsrelaterad pedagogisk forskning [Content-related educational research; in Swedish]. [Rapport 14 från forskningsgruppen för läroplansteori och kulturreproduktion]. Stockholm: Högskolan för lärarutbildning i Stockholm, Institutionen för pedagogik.

Marton, F. (1981). Phenomenography: Describing conceptions of the world around us. Instructional Science, 10, 177-200.

Marton, F. (1983). Från utbildningsmetodisk till fackdidaktisk forskning [From educational methods to content-related didactics; in Swedish]. [Rapport 100]. Linköping, Sweden: Linköpings universitet, Lärarutbildningen.

Marton, F. (Ed.). (1986). Fackdidaktik [Content-related didactics; in Swedish] (Vol. 1). Lund, Sweden: Studentlitteratur.

Marton, F. (2000). The practice of learning. Nordisk Pedagogik, 20(1), 230-236.

Pedagogik som vetenskap [Education as a science]. (1992). Forskning om Utbildning, 19(2).

Philosophy of education. (2001). Nordisk Pedagogik, 21(3).

The public and the text. (1996). Fournal of Curriculum Studies, 28(1).

Rawls, J. (1971). A theory of justice. Oxford, England: Oxford University Press.

du Rietz, L., Lundgren, U. P., \& Wennås, O. (1987). Ansvarsfördelning och styrning på skolområdet. Ett beredningsunderlag utarbetat inom utbildningsdepartementet [Division of responsibilities and management in the field of education. A discussion document prepared within the Ministry of Education; in Swedish]. [DsU 1987:1]. Stockholm: Utbildningsdepartementet.

Rorty, R. (1980). Philosophy and the mirror of nature. Oxford, England: Blackwell.

Rorty, R. (1982). Consequences of pragmatism. Minneapolis, MN: University of Minnesota Press.

Rosengren, K.-E., \& Öhngren, B. (Eds.). (1997). An evaluation of Swedish research in education. Stockholm: Swedish Council for Research in the Humanities and Social Sciences.

SOU 1990:44. Demokrati och makt $i$ Sverige [The study of democracy and power in Sweden; in Swedish]. Stockholm: State Publications.

Säfström, C.-A. (1994). Makt och mening. Förutsättningar för en innehållsfokuserad pedagogisk forskning [Power and meaning. Prerequisites for content-focused educational research; in Swedish]. [Uppsala Studies in Education 53]. Uppsala, Sweden: Acta Universitatis Upsaliensis. 
Säfström, C.-A., \& Östman, L. (Eds.). (1999). Textanalys [Text analysis; in Swedish]. Lund, Sweden: Studentlitteratur.

Säljö, R. (1990). Språk och institution. Den institutionaliserade inlärningens metaforer [Language and institution. The metaphors of institutionalized learning; in Swedish]. Forskning om Utbildning, 17(4), 5-17.

Säljö, R. (1992). Kontext och mänskliga samspel [Context and human interaction; in Swedish]. Utbildning och Demokrati, 1(2), 21-36.

Säljö, R. (1994). Minding action. Conceiving of the world versus participating in cultural practices. Nordisk Pedagogik, 14(2), 71-80.

Säljö, R. (1995). Begreppsbildning som pedagogisk drog [Concept formation as an educational drug; in Swedish]. Utbildning och Demokrati, 4(1), 5-22.

Säljö, R. (2000). Lärande i praktiken [Learning in practice; in Swedish]. Stockholm: Prisma.

Säljö, R. (2001). The individual in social practices. Nordisk Pedagogik, 21(2), 108-116.

Schilling, M. (1986). Knowledge and liberal education. Fournal of Curriculum Studies, 18(1), 1-16.

Schüllerqvist, U. (1996). Förskjutningen av svensk skolpolitisk debatt under det senaste decenniet [The shift in Swedish educational policy debate over the last decade; in Swedish]. In T. Englund (Ed.), Utbildningspolitiskt systemskifte? (pp. 44-106). Stockholm: HLS Förlag.

Telhaug, A. O. (1990). Den nye utdanningspolitiske retorikken [The new educational policy rhetoric; in Norwegian]. Oslo, Norway: Universitetsforlaget.

Undervisning som kommunikation [Education as communication]. (1993). Utbildning och Demokrati, 2(1).

Young, M. (Ed.). (1971). Knowledge and control. New directions for the sociology of education. London: Macmillan. 
Copyright of Scandinavian Journal of Educational Research is the property of Routledge and its content may not be copied or emailed to multiple sites or posted to a listserv without the copyright holder's express written permission. However, users may print, download, or email articles for individual use. 